\title{
Hypocrealean Fungi Associated with Hylobius abietis in Slovakia, Their Virulence against Weevil Adults and Effect on Feeding Damage in Laboratory
}

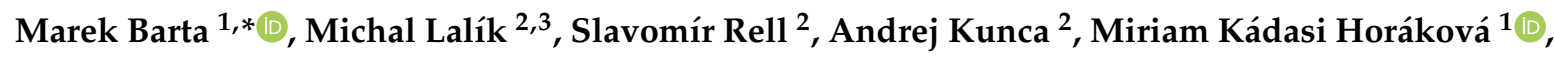 \\ Silvia Mudrončeková ${ }^{4}$ and Juraj Galko ${ }^{2}$ \\ 1 Institute of Forest Ecology, Slovak Academy of Sciences, Akademická 2, 94901 Nitra, Slovak Republic \\ 2 National Forest Centre, Forest Research Institute Zvolen, T.G. Masaryka 22, 96001 Zvolen, Slovak Republic \\ 3 Department of Forest Protection and Entomology, Faculty of Forestry and Wood Sciences, \\ Czech University of Life Sciences Prague, Kamýcká 1176, 16500 Prague 6, Czech Republic \\ 4 Research Station of State Forests of TANAP, 05960 Tatranská Lomnica, Slovak Republic \\ * Correspondence: marek.barta@savba.sk; Tel.: +421-376-943-354
}

Received: 4 July 2019; Accepted: 25 July 2019; Published: 27 July 2019

check for updates

\begin{abstract}
In temperate regions of Europe, the large pine weevil, Hylobius abietis, is a major pest of coniferous forests mostly at sites where clear-felling is followed by planting of saplings. Control measures against this pest are based on silvicultural techniques, an application of physical barriers on stems of saplings and insecticide treatments. To avoid the use of insecticides, alternative measures such as biological control have been investigated. The goal of the present study was to obtain local strains of entomopathogenic fungi (Ascomycota, Hypocreales) from natural populations of $H$. abietis, and to investigate their efficacy against the weevil. A survey on entomopathogenic fungi was undertaken at clear-felled areas of spruce forests in northern Slovakia. Two Beauveria species, B. bassiana and B. pseudobassiana, were identified, and 22 in vitro strains were obtained. Mean prevalence of infected adults was low $(2.10 \% \pm 0.67 \%)$ and the mycosis was mostly recorded during May and June. Virulence of Beauveria strains against the weevil was tested in laboratory. B. bassiana strain AMEP20 was significantly most virulent $\left(\mathrm{LC}_{50}\right.$ of $0.65 \pm 0.10 \times 10^{8}$ conidia $\mathrm{mL}^{-1}$ ). Treatment with conidia of AMEP20 strain affected feeding damage by the weevil on bark of Scots pine twigs. Daily bark consumption by B. bassiana-treated weevils was lower than by untreated individuals and decreased with increasing conidia concentration used for the treatment. In the outdoor experiment, AMEP20 strain killed weevils that fed on spruce saplings treated with conidia suspensions. Mortality due to mycosis on weevils exposed to the conidia-treated saplings reached $30.0 \%-76.5 \%$ and $55.0 \%-88.2 \%$ after 32 and 46 days, respectively.
\end{abstract}

Keywords: biocontrol; entomopathogenic fungi; Hylobius abietis; Hypocreales; virulence

\section{Introduction}

The large pine weevil, Hylobius abietis L. (Curculionidae: Molitynae), is regarded as one of the most damaging pests of newly planted or naturally regenerating coniferous forests across Northern and Western Europe [1,2]. This Palearctic species is naturally distributed from the north-west of Europe to Siberia [3]. Larvae develop inside cambial tissues of underground parts of stumps of felled coniferous trees, and adults feed on bark of young saplings. Adult weevils may cause considerable economic loss by damaging the bark, what often leads to sapling mortality, or reduced growth with stem deformations. In some cases, a complete destruction of new plantations occurs, especially where clear-felling is immediately followed by planting of coniferous saplings [1,2,4-6]. A single weevil can damage several saplings [7]. Thus, a relatively low number of adults can have a significant impact on regeneration of 
reforestation areas. Moreover, weevils can migrate more than $10 \mathrm{~km}$ and can therefore cause damage over a broad area [8]. In laboratory assays, a polyphagous habit of adults was demonstrated, although coniferous species were always preferred [9]. While a range of coniferous host tree species is wide [10], Scots pine (Pinus sylvestris (L.)) and Norway spruce (Picea abies (L.) H. Karst) are the main hosts [11].

Thousands of hectares of reforestation sites are annually threatened by H. abietis in Europe [12]. If the sites are left unprotected, economic losses to the forest industry can be severe. In Slovakia, H. abietis population density has been considerably increasing since 2010 and spruce saplings in reforestation areas have been significantly damaged [13-15]. Control measures against $H$. abietis are mostly based on a range of silvicultural techniques (e.g., removal of breeding material after felling, delayed planting, shelter-wood planting system, mixed planting, and timing of felling), and an application of physical barriers on stems of saplings before or at planting (e.g., latex paint, PVC (polyvinyl chloride) barriers, sand (Conniflex) and glue based stem coating, and wax coating) [2,16-25]. The curative insecticide application is usually not efficient due to a sheltered lifecycle of larval stage [26]. Therefore, the preventive use of insecticides on saplings before planting is the main control measure currently employed in most countries, which practice reforestation [2,27]. Because weevils are able to detect some insecticides (pyrethroids and nicotinoids) and to avoid treated saplings, insecticide treatments protect young saplings, but have little impact on local populations of the pest $[18,26]$.

Although the pesticide use in forestry is small compared to agriculture and horticulture (on average $0.10 \%-1.10 \%$ of total volume used in Slovakia during 2000-2015 [28]), its minimization and reducing the risk of damage to the environment is an important task of an integrated approach for managing forest pests. To avoid the use of insecticides, alternative measures such as biological control and their suitability for the $H$. abietis control have been investigated. Several natural antagonists of pine weevils, including entomopathogenic nematodes, fungi and microsporidia, have been studied as potential biocontrol agents [29-35]. Over the last two decades, more attention was put to nematodes (families Steinernematidae and Heterorhabditidae) for inundative biocontrol targeted against pine weevil larvae, pupae, and callow adults $[29,30,32,34]$. Although nematodes can reduce numbers of emerging $H$. abietis adults, there is an increasing interest to apply entomopathogenic fungi (Ascomycota, Hypocreales) against larvae and pupae, since they possess several properties, which make them more suitable for weevil control. They infect all developmental stages, have a better shelf-life of inoculum, have a longer persistence in the field with a potential to be augmented by mycosed individuals, and finally a fungal inoculum application is technically less complicated than in the case of nematodes [36].

Entomopathogenic fungi (EPF) are natural antagonists of arthropods helping in control of host population and prevention of outbreaks formation [37]. There has been an extensive research on the use of fungal entomopathogens as perspective biocontrol agents of insect pests in agriculture and forestry [38], and some strains have been successfully licensed and commercialised [39,40]. These fungi are considered to be environmentally safe [41], can be mass-produced [42], and show a considerable potential to control various forest insect pests [43]. In Europe, several reports have focused on the occurrence of EPF in H. abietis populations, and species of Beauveria and Metarhizium genera have been reported from larvae and adults. Generally, the fungi are associated with $H$. abietis populations at a relatively low, though a constant prevalence level $[32,35,44,45]$. Results of earlier and recent attempts to use EPF against $H$. abietis in laboratory were either inconsistent or not very promising [32,36,46-50]. In spite of that, the fungi are believed to have a potential to be successfully implemented into an integrated system managing the problem of pine weevil damage. Feasibility and sustainability of their use as control agents of $H$. abietis in the field depend on the choice of fungal strains, inoculum formulations, and application techniques.

The present study aims to identify entomopathogenic fungi in natural populations of $H$. abietis in Slovakia, to obtain local strains of the fungi and to investigate their virulence against the weevil in laboratory and semi-field bioassays with testing their effect on feeding damage. 


\section{Materials and Methods}

\subsection{Collecting and Handling of Weevils}

Pitfall traps $[4,5,51,52]$ baited with $96 \%$ ethanol and $50 \mathrm{~mm}$ long pieces of Scots pine twigs were used for trapping $H$. abietis adults at several clear-felled areas of spruce forests in northern Slovakia. Most of trappings were conducted at the High Tatra Mountains in the Tatra National Park $\left(49^{\circ} 10^{\prime} 0^{\prime \prime} \mathrm{N}\right.$, $20^{\circ} 08^{\prime} 0^{\prime \prime} \mathrm{E}$ ) and at the Low Tatra Mountains ( $48^{\circ} 57^{\prime} 0^{\prime \prime} \mathrm{N}, 1^{\circ} 30^{\prime} 0^{\prime \prime} \mathrm{E}$ ) during 2015-2018, where generally high damage by the weevils had been determined during our earlier investigations. During 2015-2017 the trapping was neither extensive nor systematic and traps were installed and checked irregularly. In 2018, the traps in the Tatra National Park were checked regularly once a week from the end of April to September to determine the prevalence of fungal infection in pest population. All trapped weevils were placed into rectangular plastic boxes $(250 \times 150 \times 150 \mathrm{~mm})$ in groups of 50 individuals per box and incubated $\left(20^{\circ} \mathrm{C}\right.$ and $80 \%$ relative humidity $(\mathrm{RH})$ ) for 21 days to observe a natural prevalence of entomopathogenic fungi. Each dead weevil displaying typical macroscopic symptoms of fungal infection was placed in a $1.5 \mathrm{~mL}$ microtube and stored at $5{ }^{\circ} \mathrm{C}$ until used for obtaining fungal cultures. Dead adults displaying no external symptoms were incubated individually in Petri dishes $(60 \times 15 \mathrm{~mm})$ on a piece of wet filter paper at $25^{\circ} \mathrm{C}$ for $72 \mathrm{~h}$ to stimulate fungal growth. All cadavers with characteristic symptoms of mycosis were examined under a dissecting microscope $(40 \times)$ to detect possible contaminants or death caused by other factors. Fungal cultures were obtained from the individuals with confirmed fungal infection.

For virulence bioassays, collected weevils were separated according to sex and kept in plastic boxes $(150 \times 10 \times 80 \mathrm{~mm})$ at $5-7^{\circ} \mathrm{C}$ for a maximum of two months prior to their use. The weevils were provided with fresh food (Scots pine twigs) and kept at $20{ }^{\circ} \mathrm{C}$ and $60 \pm 10 \% \mathrm{RH} 48 \mathrm{~h}$ before the experiments.

For bioassays with a measurement of feeding damage, the weevils separated to males and females starved at $20^{\circ} \mathrm{C}$ and $60 \pm 10 \% \mathrm{RH}$ for $48 \mathrm{~h}$ before the experiment to ensure the consistency in feeding damage between replicates.

\subsection{In Vitro Isolation and Identification of Entomopathogenic Fungi}

In vitro isolates of EPF were obtained from infected weevils using a selective culture medium (Sabouraud-dextrose agar (SDA) supplemented with $600 \mathrm{mg} \cdot \mathrm{L}^{-1}$ streptomycin sulphate, $50 \mathrm{mg} \cdot \mathrm{L}^{-1}$ tetracycline hydrochloride, $250 \mathrm{mg} \cdot \mathrm{L}^{-1}$ cyclohexamide, and $500 \mathrm{mg} \cdot \mathrm{L}^{-1}$ dodine (all chemicals from Sigma-Aldrich ${ }^{\circledR}$, Saint Louis, MI, USA)). Isolated colonies were sub-cultured on SDA without antibiotics and fungicides in culture glass tubes at $25 \pm 1{ }^{\circ} \mathrm{C}$ in the dark for 10 days and sporulating cultures were stored at $5{ }^{\circ} \mathrm{C}$. All obtained isolates were deposited in the fungal collection of the Institute of Forest Ecology of the Slovak Academy of Sciences (Nitra, Slovakia).

The in vitro cultures were microscopically $(500 \times)$ identified to a genus level according to morphology of microstructures [53-55]. The morphological identification was supplemented by a sequencing study of internal transcribed region (ITS) of rDNA and a partial sequence of TEF1- $\alpha$ gene. DNA of fungi was isolated using EZ-10 Spin Column Fungal Genomic DNA Kit (Bio Basic Canada Inc., Ontario, Canada) according to the manufacturer's instructions. The ITS region was amplified with a primer pair ITS1-F/ITS4 [56,57] and the TEF-1 $\alpha$ gene with primers 983F and 2218R [54]. PCR products were purified by QIAquick PCR Purification Kit (Qiagen n.v., Venlo, Netherlands) and sequenced using the primers ITS4 or 983F (Macrogen Europe Inc., Amsterdam, The Netherlands). Obtained sequences were subjected to Blast N [58] against GenBank Nucleotide Database for taxonomic classification. All sequences obtained from this study were deposited in GenBank (Table 1).

\subsection{Fungal Strains}

Fungal strains obtained from naturally killed $H$. abietis (Table 1) were cultivated on Sabourauddextrose agar (SDA) in polystyrene Petri dishes $(94 \times 16 \mathrm{~mm})$ at $25 \pm 1^{\circ} \mathrm{C}$ in the dark for 5 days and 
under the continuous light for the next 5 days. The 10-day-old sporulating cultures were stored at $4{ }^{\circ} \mathrm{C}$ prior to their use in bioassays, but not longer than two weeks. A percentage of viable conidia was determined prior to each bioassay by germination tests on agar plates [59]. Conidial viability of all isolates used for tests was $>95 \%(\bar{x}=96.63 \pm 0.20 \%)$ measured after $12 \mathrm{~h}$ incubation on an agar plate at $25^{\circ} \mathrm{C}$.

Table 1. List of Beauveria strains isolated from naturally infected adults of Hylobius abietis in Slovakia during 2015-2018.

\begin{tabular}{|c|c|c|c|}
\hline \multirow{2}{*}{ Strain } & \multirow{2}{*}{ Fungal Species } & \multicolumn{2}{|c|}{ GenBank Accession No. ${ }^{1}$} \\
\hline & & ITS & TEF-1 $\alpha$ \\
\hline AMEP020 & Beauveria bassiana & MK490859 & MK504338 \\
\hline AMEP043 & Beauveria pseudobassiana & MK490860 & MK504354 \\
\hline AMEP052 & Beauveria bassiana & MK490861 & MK504339 \\
\hline AMEP053 & Beauveria bassiana & MK490862 & MK504340 \\
\hline AMEP056 & Beauveria bassiana & MK490863 & MK504341 \\
\hline AMEP067 & Beauveria pseudobassiana & MK490864 & MK504355 \\
\hline AMEP072 & Beauveria bassiana & MK490865 & MK504342 \\
\hline NREP083 & Beauveria pseudobassiana & MK490866 & MK504356 \\
\hline NREP084 & Beauveria pseudobassiana & MK490867 & MK504357 \\
\hline NREP087 & Beauveria bassiana & MK490868 & MK504343 \\
\hline NREP088 & Beauveria bassiana & MK490869 & MK504344 \\
\hline NREP090 & Beauveria bassiana & MK490870 & MK504345 \\
\hline NREP091 & Beauveria bassiana & MK490871 & MK504346 \\
\hline NREP094 & Beauveria bassiana & MK490872 & MK504347 \\
\hline NREP095 & Beauveria bassiana & MK490873 & MK504348 \\
\hline NREP096 & Beauveria bassiana & MK490874 & MK504349 \\
\hline NREP097 & Beauveria bassiana & MK490875 & MK504350 \\
\hline NREP098 & Beauveria bassiana & MK490876 & MK504351 \\
\hline NREP099 & Beauveria pseudobassiana & MK490877 & MK504358 \\
\hline NREP100 & Beauveria bassiana & MK490878 & MK504352 \\
\hline NREP102 & Beauveria bassiana & MK490879 & MK504353 \\
\hline NREP103 & Beauveria pseudobassiana & MK490880 & MK504359 \\
\hline
\end{tabular}

${ }^{1}$ GenBank Accession numbers of DNA sequences for ITS and TEF- $1 \alpha$ regions submitted to GenBank database.

\subsection{Virulence Bioassays against $H$. abietis Adults}

A stock suspension of conidia was prepared by suspending a mycelial mat in $250 \mathrm{~mL}$ of $0.01 \%$ (w/v) Tween ${ }^{\circledR} 80$ inside a $500 \mathrm{~mL}$ reagent flask. The flask was hand-shaken for $60 \mathrm{~s}$ and mycelial debris were removed from the suspension by filtration through a sterile $10 \mu \mathrm{m}$ nylon membrane (Spectra Mesh $^{\circledR}$, Spectrum Chemical Mfg. Corp., New Brunswick, NJ, USA). Concentration of conidia was determined using an improved Neubauer hemocytometer, and the required concentration of the stock suspension was obtained by dilution in $0.01 \%(\mathrm{w} / \mathrm{v})$ Tween ${ }^{\circledR} 80$. The conidia suspensions were used immediately for virulence bioassays. A median lethal concentration of conidia $\left(\mathrm{LC}_{50}\right)$ for $H$. abietis was estimated from cumulative mortality data at four different conidia concentrations ranging from $1 \times 10^{6}$ to $1 \times 10^{9}$ conidia $\mathrm{mL}^{-1}$ in $0.01 \%(\mathrm{w} / \mathrm{v})$ Tween ${ }^{\circledR} 80$. Groups of 15 males and females were treated by their submersion in the suspensions for $10 \mathrm{~s}$, and additional 15 males and females were treated with sterile $0.01 \%$ Tween ${ }^{\circledR} 80$ as controls. Each group of treated and control weevils was incubated in Petri dishes $(200 \times 35 \mathrm{~mm})$ lined with wet filter paper at $22 \pm 1{ }^{\circ} \mathrm{C}$, saturated humidity and $12 / 12 \mathrm{~h}(\mathrm{~L} / \mathrm{D})$ photoperiod for 21 days. Five sections of Scots pine twigs (100-150 mm) were provided as food to each Petri dish. The pine twigs were superficially disinfected by germicidal (UV-C) irradiation for $30 \mathrm{~min}$ under aseptic conditions of a laminar flow cabinet before their use as food. The weevils were monitored at $24 \mathrm{~h}$ intervals to record their daily mortality. All cadavers were incubated separately in sterile Petri dishes $(60 \times 15 \mathrm{~mm})$ on a piece of wet filter paper for 5 days to facilitate fungal development. Mortality caused by the fungi was confirmed by microscopic examination and only cadavers with confirmed 
infection were used to estimate virulence. Three most virulent Beauveria strains were selected and used to repeat the bioassay under the same conditions five times.

\subsection{Feeding Damage Bioassay}

The most virulent B. bassiana strain (AMEP20) was used in a laboratory bioassay to measure an effect of the fungal treatment on feeding damage by the weevils. Adults (15 males and 15 females) were individually inoculated by conidia suspensions at four concentration levels (from $1 \times 10^{5}$ to $1 \times 10^{8}$ conidia $\mathrm{mL}^{-1}$ ) as described above, and additional groups of 15 males and 15 females were treated with sterile $0.01 \%(\mathrm{w} / \mathrm{v})$ Tween ${ }^{\circledR} 80$ as controls. The inoculated and control weevils were incubated individually in Petri dishes $(200 \times 35 \mathrm{~mm})$ with wet filter paper on the bottom at $22 \pm 2{ }^{\circ} \mathrm{C}$ and natural photoperiod. A freshly cut twig of Scots pine (approximately $100-\mathrm{mm}$-long and 7-mm-thick) was put into each Petri dish. The weevils were monitored for 46 days. Mortality was recorded and pine twigs were replaced by fresh ones on the day 11, 22 and 33. The amount of feeding damage on the twigs was assessed with a modified method by Leather et al. [60]. A damage outline on the twigs was traced onto a piece of transparent graph paper twisted around the surface of twigs with a black pen. The number of millimetre squares occluded by the trace pattern was counted, and the damaged area was calculated for each twig. Dead weevils were processed as described in the virulence bioassay. The experiment was carried out in three repetitions.

\subsection{Outdoor Bioassay with B. bassiana Treatment}

To simulate field conditions, an outdoor trial was set-up to evaluate the effect of B. bassianatreatment on $H$. abietis adults. Two-year-old Norway spruce (Picea abies) saplings $(25-30 \mathrm{~cm} \mathrm{high)}$ were planted in pots $(10 \mathrm{~cm}$ diam., $470 \mathrm{~mL})$ and equally spaced in outdoor conditions. A group of 147 saplings was treated with conidia suspension $\left(1 \times 10^{8}\right.$ conidia $\left.\mathrm{mL}^{-1}\right)$ of AMEP20 strain using a hand atomizer. Each sapling was treated with $0.95 \mathrm{~mL}$ of the suspension. A group of 21 saplings was treated in the same way with sterile $0.01 \%(\mathrm{w} / \mathrm{v})$ Tween ${ }^{\circledR} 80$ as controls. Another group of 21 saplings was also treated with sterile $0.01 \%(\mathrm{w} / \mathrm{v})$ Tween ${ }^{\circledR} 80$ as mentioned above. This group was used for a direct treatment trial. Every treated plant was inserted into a sleeve made of white polyamide mesh (aperture of $0.5 \mathrm{~mm}$ ) to prevent $H$. abietis adults from escaping. A single unsexed adult of $H$. abietis was released to each of 21 control saplings and 21 suspension-treated saplings on the day of treatment (day 0). During the following six days (days 1-6), further groups of 21 suspension-treated saplings were infested with $H$. abietis adults every day. Together, 147 suspension-treated and 21 control saplings were infested with a single $H$. abietis. The group of 21 Tween ${ }^{\circledR} 80$-traeted saplings were infested on the day 0

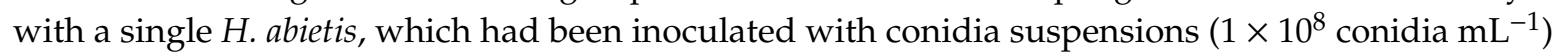
as described in the virulence bioassay (a direct treatment). Mortality of $H$. abietis was checked twice during the bioassay, 32 and 46 days after the saplings were infested with weevils. The bioassay started on 12 May and ended on 27 June 2018. Mean daily temperature varied from 11.9 to $21.0^{\circ} \mathrm{C}\left(\bar{x}=16.7^{\circ} \mathrm{C}\right)$ during the bioassay, and daily precipitation total ranged from 0 to $8.8 \mathrm{~mm}(\Sigma=30.4 \mathrm{~mm})$. Daily temperature and precipitation data that were obtained from a local automatic meteorological station are displayed in Figure 1.

\subsection{Data Analysis}

Cumulative mortality data from the virulence tests were corrected for natural (control) mortality using Schneider-Orelli's formula and subjected to probit analysis to estimate median lethal concentrations $\left(\mathrm{LC}_{50}\right)$ with associated $95 \%$ confidence intervals. A $\mathrm{LC}_{50}$ ratio [61] was calculated for each fungal strain to determine whether LC for females significantly differed from LC for males. Lethal concentrations for the most virulent strains were subjected to ANOVA and the post-hoc Tukey's HSD test was performed to separate and compare means if significant differences $(\alpha=0.05)$ were detected. Chi-square test was used for testing a hypothesis that there is no difference $(\alpha=0.05)$ in the mortality occurrence between $H$. abietis adults directly treated with conidia suspension and adults exposed to 
saplings treated with conidia in the outdoor bioassay. All the analyses were conducted using Minitab $17^{\circledR}$ (C) 2013 Minitab Inc., State College, PA, USA).

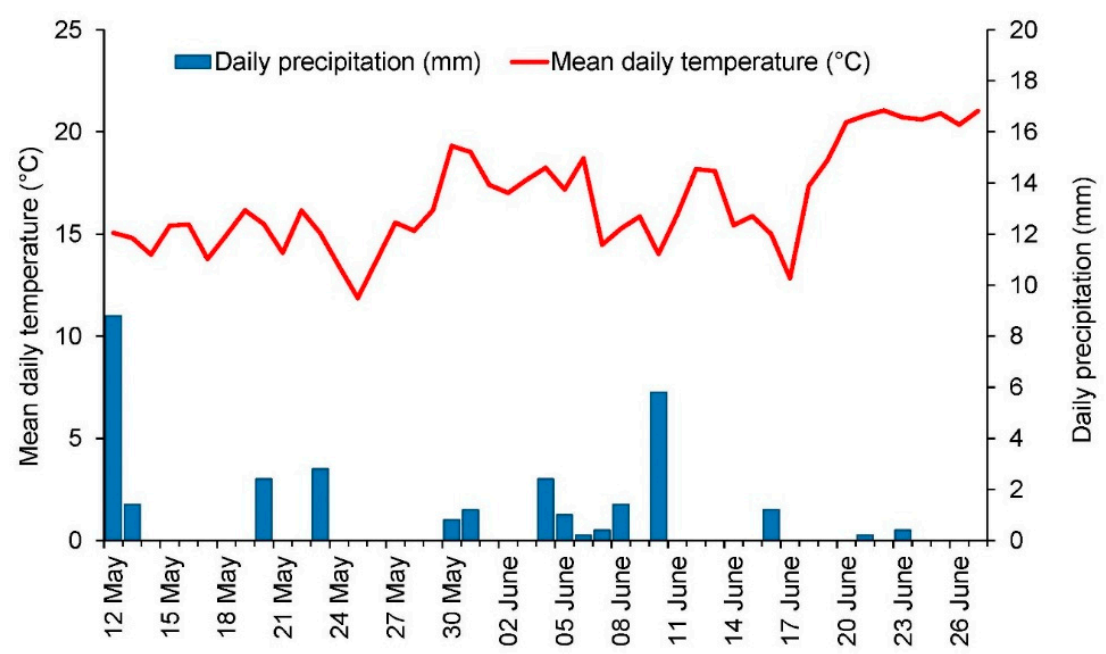

Figure 1. Daily mean temperature $\left({ }^{\circ} \mathrm{C}\right)$ and daily precipitation $(\mathrm{mm})$ data measured during the outdoor experiment.

\section{Results}

\subsection{Occurrence of Entomopathogenic Fungi in Populations of H. abietis}

During the four-year investigation on the occurrence of EPF in populations of $\mathrm{H}$. abietis, weevils killed by Beauveria sp. were observed. As many as 53 cadavers were inspected and Beauveria sp. was identified in 42 of them. Altogether, 22 in vitro isolates of EPF (Table 1) were obtained from the inspected cadavers and two Beauveria species were identified, namely B. bassiana (Bals.-Criv.) Vuill. (16 isolates) and B. pseudobassiana S.A. Rehner and R.A. Humber (6 isolates). Prevalence of mycosis in host populations was only quantified at the locality of the Tatra National Park in 2018. During this year, out of 1188 trapped adults, 25 individuals (2.10\%) displayed symptoms of Beauveria infection that was confirmed by microscopic and molecular techniques. Incidence of infected adults was low in population and varied between 0 and $5.97 \%$ depending on collecting date. Infected individuals were mostly found in May and June and prevalence of disease culminated in the second half of June. No mycosis was observed after July 7.

\subsection{Virulence of Fungal Strains against H. abietis Adults}

Pathogenicity of the Beauveria strains against weevils was tested in a series of laboratory bioassays. Percentage cumulative mortality increased with conidia concentrations and varied among fungal strains. Depending on strains, cumulative mortality reached $0-26.67 \%(\bar{x}=9.55 \% \pm 0.90 \%)$ at the lowest conidia concentration $\left(1 \times 10^{6}\right.$ conidia $\left.\mathrm{mL}^{-1}\right)$ and $46.67 \%-86.67 \%(\bar{x}=63.94 \% \pm 1.52 \%)$ at the highest concentration $\left(1 \times 10^{9}\right.$ conidia $\left.\mathrm{mL}^{-1}\right)$. Mean cumulative mortality in the control was $1.21 \% \pm 0.08 \%$ for males and $0.53 \% \pm 0.05 \%$ for females. Median lethal mortality $\left(\mathrm{LC}_{50}\right)$ varied among the strains (Table 2) and ranged from 0.52 to $13.28 \times 10^{8}$ conidia $\mathrm{mL}^{-1}$. Low variability in $\mathrm{LC}_{50}$ values between males and females was detected but $\mathrm{LC}_{50}$ ratio analysis showed no significant differences (Table 2). The most virulent strains of B. bassiana (AMEP20) and B. pseudobassiana (AMEP43 and NREP84) with estimated $\mathrm{LC}_{50}$ around $1 \times 10^{8}$ conidia $\mathrm{mL}^{-1}$ were selected to repeat the virulence bioassay five times. In this case, since sex of weevils had no effect on susceptibility to fungal infection $\left(F_{(1,8)}=0.34, p>0.05\right.$ for AMEP20; $F_{(1,8)}=0.74, p>0.05$ for AMEP43; $F_{(1,8)}=0.25, p>0.05$ for NREP84), mortality data for males and females were pooled before subjecting to probit analysis. Mean $\mathrm{LC}_{50}$ values for the three most virulent strains are shown in Table 3. AMEP20 strain with $\mathrm{LC}_{50}$ of $0.65 \pm 0.10 \times 10^{8}$ conidia $\mathrm{mL}^{-1}$ was significantly $\left(F_{(2,12)}=31.01, p<0.01\right)$ more virulent than the other two strains. 
Table 2. Summary of probit analysis parameters from the virulence bioassays performed with Beauveria spp. strains against males (M) and females (F) of Hylobius abietis in laboratory.

\begin{tabular}{|c|c|c|c|c|c|c|}
\hline Strain & Sex & $\begin{array}{c}\mathrm{LC}_{50} \pm \mathrm{SE}^{1} \\
\times 10^{8}\end{array}$ & $\begin{array}{c}95 \% \text { Fiducial } \\
\text { Confidence Interval } 1\end{array}$ & $\begin{array}{l}\text { Slope } \pm \\
\text { SE }^{2}\end{array}$ & $\begin{array}{l}\mathrm{LC}_{50} \\
\text { Ratio }^{3}\end{array}$ & $\begin{array}{l}\text { 95\% Confidence } \\
\text { Interval }^{3}\end{array}$ \\
\hline \multirow{2}{*}{ AMEP20 } & $\mathrm{M}$ & $0.52 \pm 0.03$ & $0.07-1.71$ & $0.36 \pm 0.10$ & \multirow[b]{2}{*}{38.42} & \multirow{2}{*}{$0.24-610$} \\
\hline & $\mathrm{F}$ & $0.78 \pm 0.06$ & $0.08-4.30$ & $0.29 \pm 0.09$ & & \\
\hline \multirow{2}{*}{ AMEP43 } & M & $1.05 \pm 0.12$ & $0.22-3.17$ & $0.42 \pm 0.11$ & \multirow{2}{*}{2.52} & \multirow{2}{*}{$0.10-62.46$} \\
\hline & $\mathrm{F}$ & $1.07 \pm 0.10$ & $0.21-3.51$ & $0.40 \pm 0.11$ & & \\
\hline \multirow{2}{*}{ AMEP52 } & M & $1.88 \pm 0.11$ & $0.04-8.56$ & $0.39 \pm 0.12$ & \multirow{2}{*}{0.88} & \multirow{2}{*}{$0.02-47.75$} \\
\hline & $\mathrm{F}$ & $2.23 \pm 0.14$ & $0.06-11.56$ & $0.36 \pm 0.10$ & & \\
\hline \multirow{2}{*}{ AMEP53 } & M & $6.89 \pm 0.40$ & $0.18-107.91$ & $0.56 \pm 0.23$ & \multirow{2}{*}{1.60} & \multirow{2}{*}{$0.01-307$} \\
\hline & $\mathrm{F}$ & $5.51 \pm 0.40$ & $0.16-71.72$ & $0.40 \pm 0.12$ & & \\
\hline \multirow{2}{*}{ AMEP56 } & $\mathrm{M}$ & $8.07 \pm 0.89$ & $0.13-904.89$ & $0.31 \pm 0.13$ & \multirow{2}{*}{98.44} & \multirow{2}{*}{$0.08-1059$} \\
\hline & $\mathrm{F}$ & $9.79 \pm 0.13$ & $0.14-736.54$ & $0.25 \pm 0.11$ & & \\
\hline \multirow{2}{*}{ AMEP67 } & M & $4.21 \pm 0.35$ & $0.08-136.59$ & $0.34 \pm 0.13$ & \multirow{2}{*}{2.17} & \multirow{2}{*}{$0.01-1235$} \\
\hline & $\mathrm{F}$ & $4.29 \pm 0.37$ & $0.09-130.50$ & $0.30 \pm 0.10$ & & \\
\hline \multirow{2}{*}{ AMEP72 } & $\mathrm{M}$ & $10.28 \pm 0.70$ & $0.27-316.51$ & $0.58 \pm 0.29$ & \multirow{2}{*}{1.03} & \multirow{2}{*}{$0.01-812$} \\
\hline & $\mathrm{F}$ & $8.12 \pm 0.73$ & $0.19-470.10$ & $0.36 \pm 0.12$ & & \\
\hline \multirow{2}{*}{ NREP83 } & M & $3.15 \pm 0.19$ & $0.08-16.75$ & $0.43 \pm 0.14$ & \multirow{2}{*}{14.10} & \\
\hline & $\mathrm{F}$ & $1.93 \pm 0.13$ & $0.05-11.16$ & $0.34 \pm 0.10$ & & $0.01-425$ \\
\hline & M & $1.01 \pm 0.19$ & $0.09-8.46$ & $0.27 \pm 0.10$ & & \\
\hline NREP84 & $\mathrm{F}$ & $0.76 \pm 0.05$ & $0.11-3.10$ & $0.33 \pm 0.10$ & 1.24 & $0.02-88.43$ \\
\hline NRFP87 & $\mathrm{M}$ & $4.97 \pm 0.28$ & $0.13-35.86$ & $0.52 \pm 0.20$ & 416 & $003-676$ \\
\hline NREP8/ & $\mathrm{F}$ & $4.36 \pm 0.34$ & $0.11-69.33$ & $0.34 \pm 0.11$ & 4.16 & $0.03-6 / 6$ \\
\hline & M & $11.73 \pm 0.14$ & $0.20-306.56$ & $0.34 \pm 0.16$ & & \\
\hline NREP88 & $\mathrm{F}$ & $13.28 \pm 0.16$ & $0.25-226.92$ & $0.32 \pm 0.12$ & 0.49 & $0.01-162$ \\
\hline & $\mathrm{M}$ & $10.28 \pm 0.70$ & $0.27-313.53$ & $0.58 \pm 0.29$ & & \\
\hline NREP90 & $\mathrm{F}$ & $10.34 \pm 0.88$ & $0.27-451.33$ & $0.41 \pm 0.14$ & 1.63 & $0.02-129$ \\
\hline NRFPQ1 & $\mathrm{M}$ & $4.03 \pm 0.22$ & $0.11-18.29$ & $0.51 \pm 0.17$ & & $007-1633$ \\
\hline NREPY1 & $\mathrm{F}$ & $2.04 \pm 0.11$ & $0.06-7.90$ & $0.41 \pm 0.11$ & 1.09 & $0.07-16.33$ \\
\hline & $\mathrm{M}$ & $2.66 \pm 0.16$ & $0.58-12.42$ & $0.44 \pm 0.15$ & & \\
\hline NREP94 & $\mathrm{F}$ & $2.23 \pm 0.14$ & $0.06-11.56$ & $0.36 \pm 0.10$ & 1.43 & $0.06-36.95$ \\
\hline & $\mathrm{M}$ & $8.32 \pm 0.50$ & $0.26-83.23$ & $0.59 \pm 0.21$ & & \\
\hline NREP95 & $\mathrm{F}$ & $6.45 \pm 0.38$ & $0.22-41.89$ & $0.50 \pm 0.15$ & 1.05 & $0.10-11.27$ \\
\hline & M & $2.17 \pm 0.16$ & $0.04-18.66$ & $0.33 \pm 0.11$ & & \\
\hline NREP96 & $\mathrm{F}$ & $1.96 \pm 0.13$ & $0.05-11.76$ & $0.33 \pm 0.10$ & 0.62 & $0.01-35.02$ \\
\hline NRFP97 & $\mathrm{M}$ & $5.09 \pm 0.43$ & $0.10-303.90$ & $0.35 \pm 0.14$ & 345 & $018-6589$ \\
\hline NREPY7 & $\mathrm{F}$ & $6.53 \pm 0.63$ & $0.14-584.54$ & $0.31 \pm 0.11$ & 3.45 & $0.18-65.89$ \\
\hline NRFPQ8 & $\mathrm{M}$ & $3.00 \pm 0.17$ & $0.07-132.97$ & $0.47 \pm 0.15$ & & \\
\hline NREP98 & $\mathrm{F}$ & $2.63 \pm 0.18$ & $0.07-190.81$ & $0.36 \pm 0.11$ & 38.98 & $0.01-208$ \\
\hline & $\mathrm{M}$ & $9.88 \pm 0.59$ & $0.29-117.43$ & $0.65 \pm 0.29$ & & \\
\hline NREP99 & $\mathrm{F}$ & $5.75 \pm 0.37$ & $0.18-481.19$ & $0.45 \pm 0.14$ & 68.92 & $0.05-886$ \\
\hline NRFP100 & $\mathrm{M}$ & $3.14 \pm 0.18$ & $0.07-157.04$ & $0.47 \pm 0.16$ & 169 & $001-523$ \\
\hline NREPIOU & $\mathrm{F}$ & $1.63 \pm 0.11$ & $0.04-8.54$ & $0.33 \pm 0.10$ & 1.69 & $0.01-523$ \\
\hline & $\mathrm{M}$ & $5.09 \pm 0.43$ & $0.10-303.92$ & $0.35 \pm 0.14$ & & \\
\hline NREPIO2 & $\mathrm{F}$ & $3.33 \pm 0.22$ & $0.09-247.68$ & $0.37 \pm 0.11$ & 0.14 & $0.01-12.64$ \\
\hline & $\mathrm{M}$ & $2.97 \pm 0.17$ & $0.08-124.13$ & $0.46 \pm 0.14$ & & \\
\hline NREP103 & $\mathrm{F}$ & $2.23 \pm 0.14$ & $0.06-115.63$ & $0.36 \pm 0.10$ & 4.14 & $0.06-2$ \\
\hline
\end{tabular}

${ }^{1}$ Median lethal concentrations $\left(\mathrm{LC}_{50}\right)$ and $95 \%$ fiducial confidence intervals from probit analysis are in conidia per milliliter of suspension; SE-Standard error of the mean; ${ }^{2}$ Slope from the regression analysis with standard error (SE); ${ }^{3} \mathrm{LC}_{50}$ ratios between males and females of $\mathrm{H}$. abietis with $95 \%$ confidence intervals [61]; Mean control mortality in the bioassays reached $1.21 \% \pm 0.08 \%$ for males and $0.53 \% \pm 0.05 \%$ for females. 
Table 3. Summary of probit analysis parameters from the virulence bioassays performed with the most pathogenic Beauveria strains against Hylobius abietis adults in laboratory.

\begin{tabular}{cccccc}
\hline Strain & $\mathbf{L C}_{\mathbf{5 0}} \pm \mathbf{S E}^{\mathbf{1}}$ & $\mathbf{9 5 \%}$ Fiducial CI & Slope $\pm \mathbf{S E}$ & $\boldsymbol{p}^{\mathbf{2}}$ & $\boldsymbol{\chi}^{\mathbf{2}}$ \\
\hline AMEP20 & $0.65 \pm 0.10 \times 10^{8} \mathrm{a}$ & $0.41-0.97 \times 10^{8}$ & $0.34 \pm 0.03$ & $<0.001$ & 2.53 \\
AMEP43 & $1.50 \pm 0.29 \times 10^{8} \mathrm{~b}$ & $1.00-2.19 \times 10^{8}$ & $0.38 \pm 0.03$ & $<0.001$ & 3.67 \\
AMEP84 & $1.47 \pm 0.34 \times 10^{8} \mathrm{~b}$ & $0.93-2.33 \times 10^{8}$ & $0.32 \pm 0.10$ & $<0.001$ & 3.37 \\
\hline
\end{tabular}

\footnotetext{
${ }^{1}$ Median lethal concentration $\left(\mathrm{LC}_{50}\right)$ and fiducial confidence intervals $(\mathrm{CI})$ are in conidia per milliliter of suspension; $\mathrm{SE}-$ standard error of the mean; $\mathrm{LC}_{50}$ values sharing the same letter are not significantly different $(\alpha=0.05$, Tukey's HSD test); ${ }^{2} p$-value for a slope from the regression analysis; ${ }^{3}$ Pearson $\chi^{2}$ goodness-of-fit test on the probit model $(\alpha=0.05, \mathrm{df}=2)$; Mean control mortality of adults was $2.15 \pm 0.22 \%$ in the bioassays.
}

A general pattern of mycosis progress in treated groups of weevils is depicted by mean cumulative mortality in Figures 2 and 3. Dynamics of disease development in tested populations depended on conidia concentrations. The first mortality due to fungal infection occurred on 6 and 12 days post-treatment $(\mathrm{dpt})$ when treated with the highest and lowest conidia concentrations, respectively. At the highest conidia concentration, the mean daily mortality during $13-18 \mathrm{dpt}(1.81 \% \pm 0.10 \%)$ was significantly higher $(p<0.01)$ than for $1-12 \mathrm{dpt}(0.34 \% \pm 0.03 \%)$ or higher $(p>0.05)$ than for $19-21 \mathrm{dpt}(1.48 \% \pm 0.17 \%)$ in the bioassay $\left(F_{(2,63)}=45.77, p<0.01\right)$. Generally, mean daily mortality for all isolates increased until a culmination on 16-18 dpt and then gradually decreased to the end of the experiment. Development of mycosis induced by the three most pathogenic strains (AMEP20, AMEP43, and NREP84) had a similar trend, but mortality culminated two to three days earlier reaching its maximum on the 14-16 days post-treatment, which was followed by a gradual decrease in counts of killed weevils.
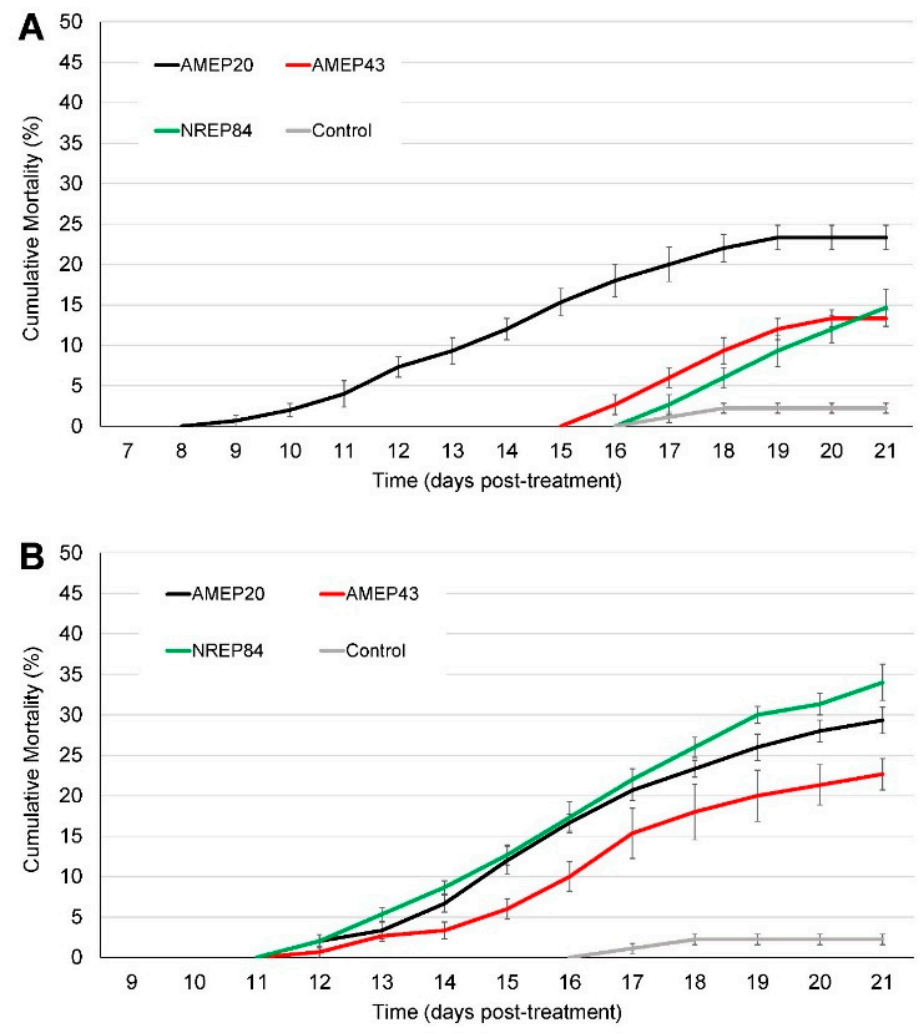

Figure 2. Mean cumulative mortality data (\%) with standard errors of Hylobius abietis adults after their inoculation with conidia suspensions of Beauveria strains at concentrations of $1 \times 10^{6}$ conidia mL $^{-1}$ (A) and $1 \times 10^{7}$ conidia $\mathrm{mL}^{-1}(\mathbf{B})$. 

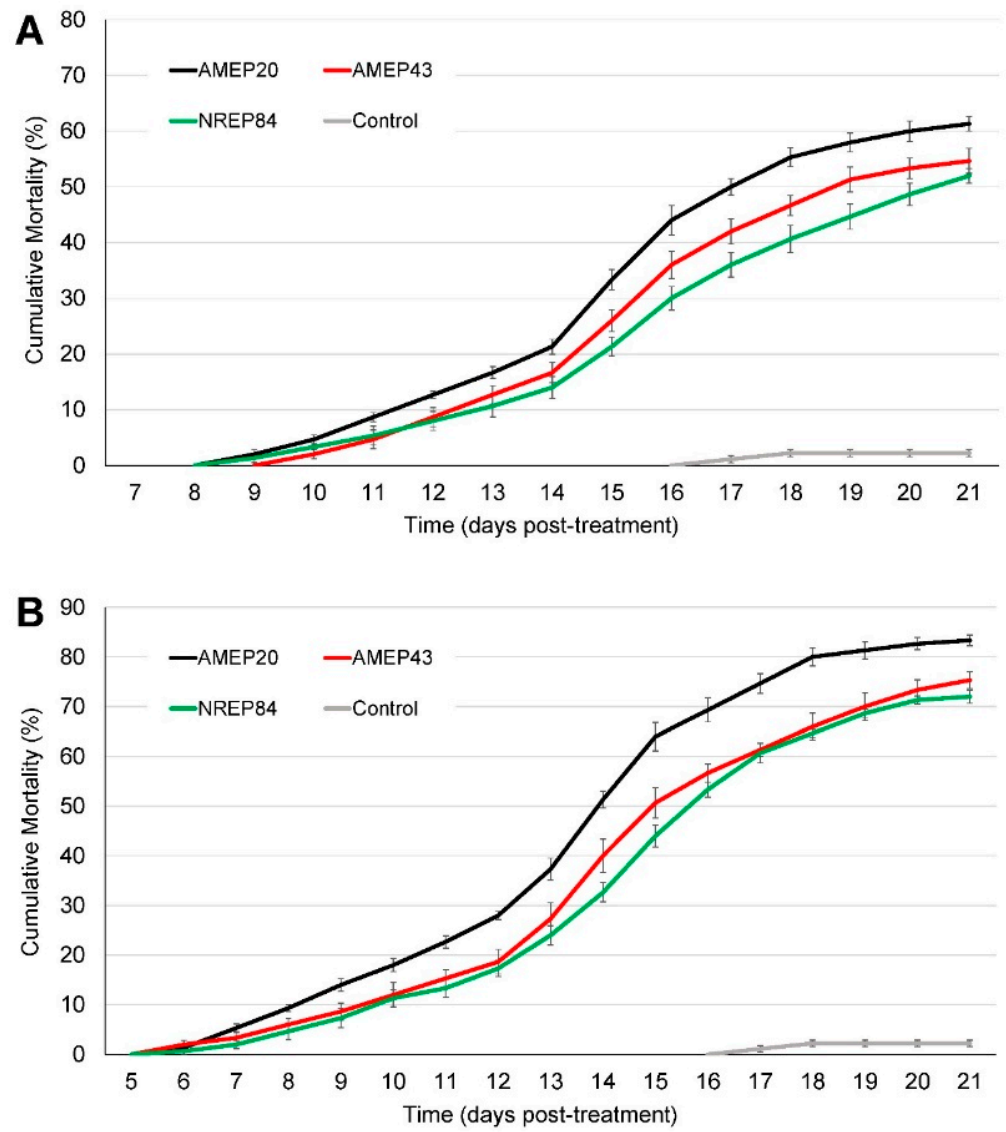

Figure 3. Mean cumulative mortality data (\%) with standard errors of Hylobius abietis adults after their inoculation with conidia suspensions of Beauveria strains at concentrations of $1 \times 10^{8}$ conidia mL $^{-1}$ (A) and $1 \times 10^{9}$ conidia $\mathrm{ml}^{-1}(\mathbf{B})$.

Out of the strains included in the pathogenicity tests, AMEP20 B. bassiana strain demonstrated the greatest biological activity against $H$. abietis adults, and mycosis by the strain developed faster in the test populations. As many as $64.00 \% \pm 2.87 \%$ weevils succumbed to infection by the strain at the highest conidia concentration $\left(1 \times 10^{9}\right.$ conidia $\left.\mathrm{mL}^{-1}\right)$ until day 15 , when mortality culmination was observed. Total cumulative mortality $(83.25 \% \pm 3.17 \%)$ induced by this strain at conidia concentration of $1 \times 10^{9}$ conidia $\mathrm{mL}^{-1}$ was significantly higher than the mortality of the other two highly virulent strains $\left(F_{(2,12)}=17.62, p<0.01\right)$, namely AMEP43 $(75.33 \% \pm 3.59 \%)$ and NREP84 $(72.00 \% \pm 4.12 \%)$. The same trend was documented for all tested conidia concentrations. Based on the above results, AMEP20 B. bassiana strain was selected for the feeding damage bioassay and the outdoor experiment.

\subsection{Feeding Damage Bioassay}

Treatment of weevils with B. bassiana inoculum affected their feeding damage on the bark of Scots pine twigs. B. bassiana-treated weevils damaged smaller area of bark per day than untreated individuals and mean daily damaged area of bark decreased with increasing conidia concentrations used for weevils treatment (Figure 4). The effect of B. bassiana on damage increased with time and was more prominent, although not significant $(p>0.05)$, at higher $\left(\geq 1 \times 10^{7}\right.$ conidia $\left.\mathrm{mL}^{-1}\right)$ conidia concentrations. While total eaten area of bark per weevil was $197.83 \mathrm{~mm}^{2}$ for untreated weevils and 197.21-227.44 $\mathrm{mm}^{2}$ for $B$. bassiana-treated weevils when evaluated $11 \mathrm{dpt}$, the consumed area per weevil for a period of 33-46 dpt dropped to $157.25 \mathrm{~mm}^{2}$ in the untreated group and to $0-88.42 \mathrm{~mm}^{2}$ for B. bassiana-treated individuals. No significant difference in feeding damage was observed between males and females either in the untreated control $\left(F_{(1,4)}=0.05, p=0.84\right)$ or after inoculating with conidia suspensions $\left(F_{(1,4)}=0.07, p=0.81\right.$ for $1 \times 10^{5}$ conidia $\mathrm{mL}^{-1} ; F_{(1,4)}=0.05, p=0.83$ for $1 \times 10^{6}$ conidia $\mathrm{mL}^{-1}$; 
$F_{(1,4)}=0.02, p=0.91$ for $1 \times 10^{7}$ conidia $\mathrm{mL}^{-1} ; F_{(1,4)}=0.08, p=0.80$ for $1 \times 10^{8}$ conidia $\mathrm{mL}^{-1}$ ). Mortality of weevils due to $B$. bassiana in the feeding damage bioassay increased with conidia concentration and time (Figure 5). No mortality was detected 11 days after treatment with any conidia concentrations. At the end of the bioassay ( $46 \mathrm{dpt}$ ), mean cumulative mortality varied from $38.89 \%$ to $100 \%$ depending on the concentration of conidia. Mean cumulative mortality in the control reached $4.44 \%$, but mycosis by B. bassiana was not confirmed in the cadavers.

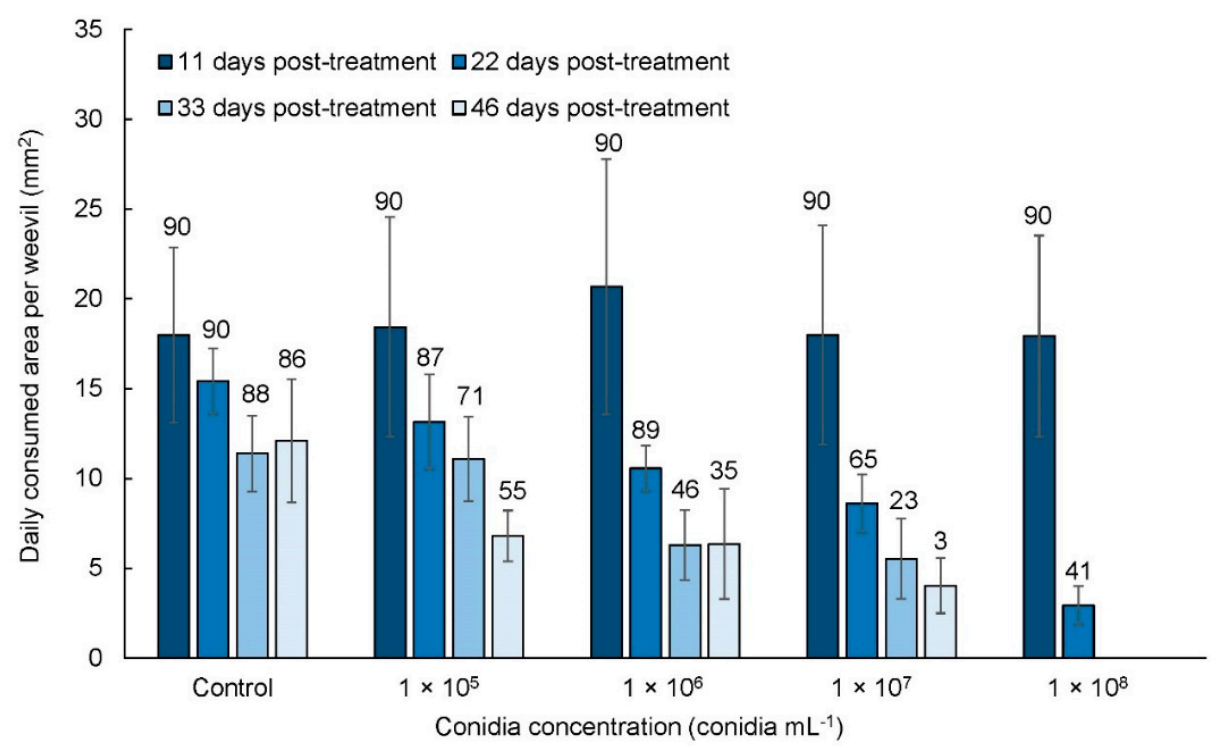

Figure 4. Mean daily damaged area $\left(\mathrm{mm}^{2}\right)$ of bark on twigs by Hylobius abietis adults after their inoculation with different conidia suspensions of Beauveria bassiana strain AMEP20. Values above bars represent numbers of surviving $H$. abietis adults on specific days post-treatment.

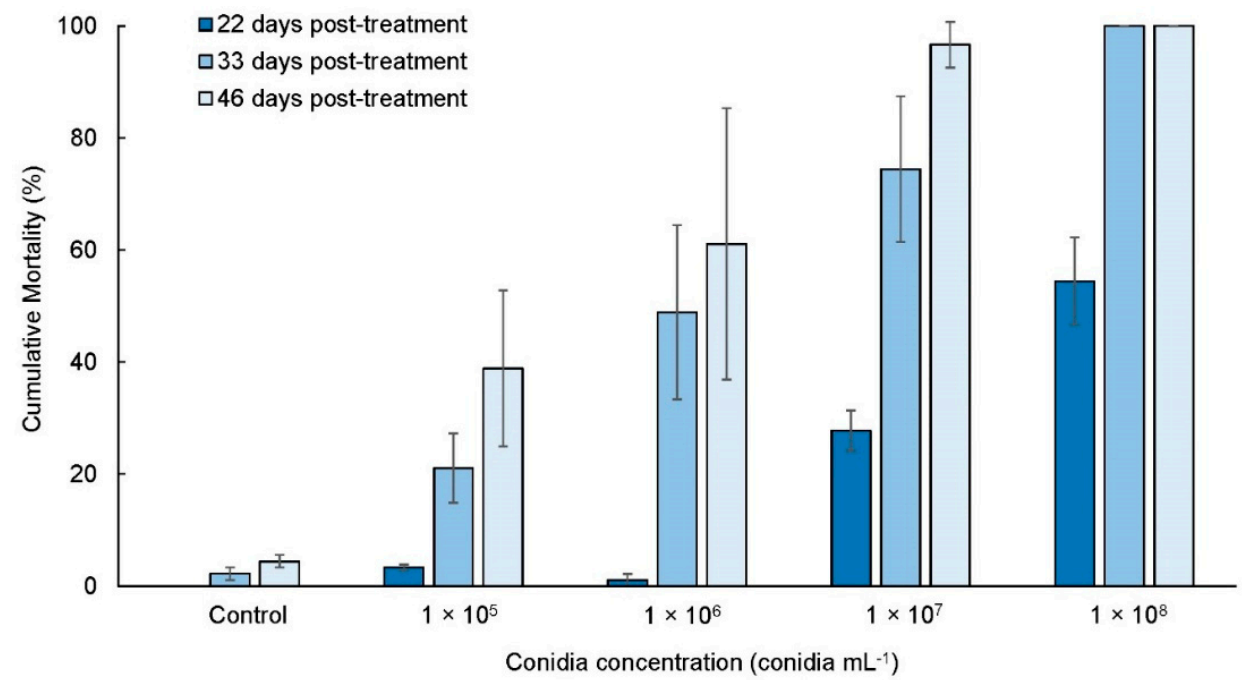

Figure 5. Mean cumulative mortality data (\%) with standard errors of Hylobius abietis adults from the feeding damage bioassay after their inoculation with conidia suspensions of Beauveria bassiana strain AMEP20.

\subsection{Outdoor Bioassay with B. bassiana Treatment}

In the outdoor experiment, AMEP20 B. bassiana strain killed weevils that had been either treated with conidia suspensions (a direct treatment) or had been allowed to feed on the saplings previously treated with the fungal inoculum (an indirect treatment) (Table 4). Total mortality of weevils after the direct conidia treatment reached $85 \%$ or $100 \%$ with confirmed B. bassiana mycosis of $65 \%$ or $85 \%$ when 
evaluated 32 or 46 days post-treatment, respectively. B. bassiana infection recorded in groups of weevils exposed to the conidia-treated saplings varied from $30.0 \%$ to $76.5 \%$ after 32 days of incubation time and from $55.0 \%$ to $88.2 \%$ after 46 days. The conidia applied on the saplings remained active during at least six days post-treatment, what was demonstrated by a mycosis development in the exposed groups of weevils. The highest level of mycosis was recorded in the group of weevils exposed to those saplings that were treated with conidia two days before. In this group of weevils, the proportion of mycosed individuals was even higher ( $76.5 \%$ or $88.2 \%$ after 32 or 46 days of incubation time, respectively) than in the group directly treated with conidia suspension $(65.0 \%$ or $85.0 \%$ after 32 or 46 days of incubation time, respectively), but the difference was not significant $(p>0.05)$. No mycosed weevils were detected on the untreated control saplings.

Table 4. Mortality of $H$. abietis adults after their direct and indirect treatment with conidia of the most virulent Beauveria bassiana strain AMEP20 in outdoor experiment.

\begin{tabular}{|c|c|c|c|c|c|c|c|c|c|c|}
\hline \multirow{2}{*}{$\begin{array}{l}\text { Incubation } \\
\text { Time }\end{array}$} & & \multirow[t]{2}{*}{ Control } & \multirow{2}{*}{$\begin{array}{c}\text { Direct } \\
\text { Treatment }\end{array}$} & \multicolumn{7}{|c|}{$\begin{array}{l}\text { Indirect Treatment-Exposure of Adults to Spruce Saplings } \\
\text { 0-6 Days Post-Treatment (dpt) }\end{array}$} \\
\hline & & & & $0 \mathrm{dpt}$ & $1 \mathrm{dpt}$ & $2 \mathrm{dpt}$ & $3 \mathrm{dpt}$ & $4 \mathrm{dpt}$ & $5 \mathrm{dpt}$ & $6 \mathrm{dpt}$ \\
\hline \multirow{3}{*}{32 days } & Mycosis & $0 \%$ & $65.0 \%$ & $60.0 \%$ & $64.7 \%$ & $76.5 \%$ & $52.9 \%$ & $30.0 \%$ & $55.0 \%$ & $31.6 \%$ \\
\hline & \multirow{2}{*}{\multicolumn{3}{|c|}{$\begin{array}{l}\chi^{2} \text { statistic }^{1} \\
p \text {-value }\end{array}$}} & 0.107 & 0.001 & 0.579 & 0.554 & 4.912 & 0.417 & 4.356 \\
\hline & & & & 0.744 & 0.985 & 0.447 & 0.457 & 0.027 & 0.519 & 0.037 \\
\hline \multirow{3}{*}{46 days } & Mycosis & $0 \%$ & $85.0 \%$ & $75.0 \%$ & $82.4 \%$ & $88.2 \%$ & $76.5 \%$ & $55.0 \%$ & $75.0 \%$ & $63.2 \%$ \\
\hline & \multirow{2}{*}{\multicolumn{3}{|c|}{$\begin{array}{c}\chi^{2} \text { statistic }{ }^{1} \\
p \text {-value }\end{array}$}} & 0.625 & 0.047 & 0.082 & 0.436 & 4.286 & 0.625 & 1.762 \\
\hline & & & & 0.429 & 0.828 & 0.774 & 0.509 & 0.038 & 0.429 & 0.184 \\
\hline
\end{tabular}

${ }^{1}$ Chi-square tests performed to determine whether there was a significant difference between the proportion of mycosed adults in direct and indirect treatments $(\alpha=0.05)$.

\section{Discussion}

EPF are important natural control agents of insects and have been a subject of an intense study since the end of the nineteenth century. More than 700 fungal species in 100 orders are estimated [43]. A great majority of perspective fungi for mass production and use in biocontrol are those from the Hypocreales (Ascomycota) order [38]. Until now, the occurrence of EPF in H. abietis populations has been poorly studied, in spite of the importance of this forest pest. From fungal pathogens of large pine weevil documented in previous studies, hypocrealean EPF, especially those of Beauveria genus, have been the most common $[35,44,45]$. Current investigations on the occurrence of EPF in field populations of $H$. abietis in Slovakia showed that Beauveria infection is consistently present but at a low prevalence level (0-5.97\%). This corresponds with results of other studies. For example, in Ireland a percentage of weevils infected with Beauveria sp. ranged from 1.3\% to 3.5\% [32]. In Europe, three Beauveria species: B. bassiana, B. brongniartii (Sacc.) Petch and B. caledonica Bissett and Widden, have been recorded from field populations of $H$. abietis to date. While $B$. bassiana was identified in this survey, we did not identify B. brongniartii and B. caledonica from any of collected individuals. On the other hand, we detected B. pseudobassiana that is the first record of this pathogenic fungus on H. abietis. Altogether, six in vitro isolates of this species were obtained from the cadavers and thus the fungus cannot be considered a rare EPF in large pine weevil populations. Recent analyses of soil samples in Slovakia indicated that B. pseudobassiana preferred forest habitats over field crops or meadows [62] assuming its better adaptation to forest ecosystems. On the other hand, this species was not identified from forest soil samples in Poland [63]. Since virulence tests ranked two strains of B. pseudobassiana (AMEP43 and NREP84) among strains possessing high efficacy against the weevils, the pathogenic potential of this fungus against forest insect pests deserves a further study. B. brongniartii is a well-known pathogen of soil inhabiting coleopteran larvae, but was also identified from larvae of $H$. abietis in Austria [35]. Its pathogenicity to $H$. abietis has also been demonstrated in laboratory experiments [49]. B. caledonica is a species originally described from moorland soil in Scotland [64] and was also found as 
a naturally-occurring pathogen of $H$. abietis and other curculionids in the northern UK, Ireland, Poland, Austria, France, Slovakia, and New Zealand [32,35,45,65,66]. Results of laboratory assays suggest that B. caledonica has a potential to be a biocontrol agent of curculionids. Bioassays with B. caledonica strains from Slovakia and New Zealand demonstrated their high pathogenicity to adults of Ips typographus (L.) (Curculionidae: Scolytinae) and other scolytid beetles [45,66]. Although pathogenicity of fungi from another hypocrealean genus, Metarhizium, to $H$. abietis was demonstrated in laboratory and field experiments $[36,50,67]$, this fungus was not found naturally infecting weevils in this survey or in other studies [32,35].

Now, it is generally accepted that a traditional morphotaxonomic determination of Beauveria species is not sufficient and an application of molecular methods is required. Most records on B. bassiana and B. brongniartii made before the comprehensive multigene phylogenetic analysis and taxonomic revision of Beauveria genus [54,55] must be judged with caution. Both taxa were complexes of species consisting of morphologically similar but cryptic lineages. Following the novel molecular approach in Beauveria taxonomy, several new species have been described [55,68-74]. Up until now, five species (B. bassiana, B. brongniartii, B. caledonica, B. pseudobassiana, and B. varroae S.A. Rehner and Humber) have been documented in Europe. While B. bassiana, B. brongniartii, and B. pseudobassiana are globally distributed soilborne entomopathogens with a broad host-range occurring in a variety of habitats, B. varroae is known only from ectoparasitic mites of honeybee in France, although it can infect also coleopteran hosts [55]. Because the previous studies on EPF diversity in field-collected large pine weevil in Europe have been based on the morphotaxonomic principles, some Beauveria species might have been misidentified or remained undetermined.

As shown in the current field surveys, Beauveria infection is one of natural factors of $H$. abietis mortality. Although natural epizootics are not typical for these fungi, laboratory and field experiments have already shown their efficacy against this forest pest $[32,36,50,67]$. Previous research on testing Beauveria spp. against $H$. abietis produced optimistic outcomes, but effective biocontrol methods using these fungi are still lacking. It is generally known that a selection of highly virulent strains is a prerequisite for successful implementation of EPF in the biocontrol of insect pests. A series of our laboratory bioassays showed that all tested Beauveria strains could infect adults of $H$. abietis and sporulate on cadavers. No effect of sex of tested weevils was detected on the susceptibility against the fungal strains. To our knowledge, B. pseudobassiana has not been tested against H. abietis yet, and the current virulence tests bring optimistic results. Based on the interspecific variability in pathogenicity of the strains we cannot conclude that any of tested Beauveria species demonstrated better results in the biological properties than the other ones. Two highly virulent B. pseudobassiana strains and one B. bassiana strain were identified in the virulence bioassays. B. bassiana strain AMEP20 was selected for further investigation due to higher mortality, and thus lower values of $\mathrm{LC}_{50}$, than mortality obtained after application of B. pseudobassiana strains.

Generally, disease development was relatively slow in tested weevils. The most virulent strain (AMEP20) caused 29.97\% cumulative mortality on day 12 and $83.25 \%$ mortality on day 21, when the highest conidia concentration $\left(1 \times 10^{9}\right.$ conidia $\left.\mathrm{mL}^{-1}\right)$ was tested. In a similar study by Ansari and Butt [36], B. bassiana strains caused 53\% mortality of $H$. abietis on day 12 , if the weevils were treated by submersion into conidia suspension $\left(1 \times 10^{8}\right.$ conidia $\left.\mathrm{mL}^{-1}\right)$. In this study, the mortality caused by AMEP20 strain and a concentration of $1 \times 10^{8}$ conidia $\mathrm{mL}^{-1}$ was $63.27 \%$ on day 21 , but it was only $16.65 \%$ on day 12. Ansari and Butt [36] explain the prolonged time to the host death by the thick and tough cuticle of adults that can form a barrier against the entomopathogenic fungi. This slow killing rate by entomopathogenic fungi might be a limitation factor for their effective use against adults of the large pine weevil. It was documented that three adults can completely strip the bark of a spruce sapling within six days [75]. On the other hand, H. abietis adults can live for up to four years [1,76] and females lay eggs each season (from May to September) during their lifetime. Considering this fact, the slow action of fungi does not seem to be such an important factor. Any measure applied to kill adults can effectively contribute to the control of weevil population. Due to the slow action of B. bassiana during the 
virulence bioassays, we also tested an effect of treatment by conidia suspensions (including sublethal concentrations) on the feeding damage by adult weevils. Treated weevils damaged significantly smaller area of bark than untreated individuals. The effect was observed for all tested conidia concentrations and was more prominent when mycosis progressed. The results clearly demonstrate that although the infected individuals lived relatively long after inoculation, their feeding on twigs was reduced resulting in smaller damage in comparison with healthy weevils. Spruce trees are the main host plants of $H$. abietis in Slovakia, but we used P. sylvestris twigs for the feeding damage experiment because this food was preferred by adult weevils when compared to P. abies [60]. There is a general agreement in several studies that optimum temperature for feeding of adult weevils is $20^{\circ} \mathrm{C}[60,77,78]$ (Christiansen and Bakke, 1968; Christiansen, 1971; Leather et al., 1994). At this temperature a weevil consumed on average $252.9 \mathrm{~mm}^{2}$ of P. sylvestris bark during 7 days [60]. In the current bioassay, an untreated (control) weevil consumed less food $\left(197.83 \mathrm{~mm}^{2}\right)$ during 11 days, and the food consumption moderately decreased towards the end of the bioassay. We do not know the reasons for the discrepancy with the previous study, but it might be related to the different quality of provided food or a different body size of adults in the studies. There is a considerable variation in the body size within natural populations of $H$. abietis and the weevil size was shown an important factor affecting a feeding rate [79].

Laboratory bioassays are usually carried out under optimal conditions for pathogenesis, which can be very different from environmental conditions in the field. Therefore, efficacy of the selected B. bassiana strain (AMEP20) was tested in outdoor conditions. It is well known that environmental factors can significantly reduce viability of $B$. bassiana inoculum when applied to the plant surface. The sunlight belongs to the most limiting factors [80-82]. Viability of conidia decreased to a half after a two-hour irradiation by simulated sunlight in laboratory [83,84]. Significant variability in conidia susceptibility to simulated sunlight exists among B. bassiana strains [85]. The conidia viability may also vary depending on the plants, on which the inoculum had been applied. For example, viability of $B$. bassiana conidia was high up to 26 days on lettuce and celery leaves [86], but it significantly decreased on Medicago sativa L. and Agropyron cristatum (M. Bieb.) P. Beauv. plants after 16 days [87] and on soya plants after 10 days [79]. In the current study, the B. bassiana conidia were active on spruce plants 6 days after its application and caused high mortality of $H$. abietis. The results also confirm that a contact of weevils with plants treated with inoculum leads to their high mortality. A similar study showed that a sustained contact of weevils with B. bassiana-treated spruce bark caused high infection rates [48]. The outcomes indicate that the application of conidia suspension on saplings could be a perspective approach in the biocontrol of $H$. abietis.

\section{Conclusions}

The current study investigated natural prevalence of EPF in populations of $H$. abietis adults and pathogenicity of local Beauveria strains against $\mathrm{H}$. abietis adults with the goal to identify those possessing a high potential for biocontrol of this pest preferably in vulnerable forest areas, e.g., national parks, nature reserves and other areas with restrictions applied in the conventional pest management. Two Beauveria species (B. bassiana and B. pseudobassiana) were active in natural populations of large pine weevil. The laboratory bioassays suggested that AMEP20 B. bassiana strain could provide an effective and an acceptable level of $H$. abietis control in laboratory and simulated field conditions. Additional studies under actual field conditions are currently being conducted to evaluate the performance of the strain in forests. In addition, horizontal transmission of infection in the host populations, inoculum formulation and its introduction into $\mathrm{H}$. abietis populations are also studied.

Author Contributions: Conceptualization, M.B., M.L., and J.G.; methodology, M.B., M.L., J.G., and M.K.H.; formal analysis M.B. and J.G.; investigation, M.B., M.L., J.G., S.R., A.K., S.M., and M.K.H.; data curation, M.B., M.L., and J.G.; writing—original draft preparation, M.B., M.L. and J.G.; writing—review and editing, M.B.; supervision, A.K.; project administration, J.G.; funding acquisition, J.G.

Funding: This research was funded by the Slovak Research and Development Agency, grant numbers APVV-16-0031 and APVV-15-0348, and by the Ministry of Agriculture and Rural Development of the Slovak Republic, grant number 08V0301. 
Conflicts of Interest: The authors declare no conflict of interest.

\section{References}

1. Leather, S.R.; Day, K.R.; Salisbury, A.N. The biology and ecology of the large pine weevil, Hylobius abietis (Coleoptera: Curculionidae): A problem of dispersal. B Entomol. Res. 1999, 89, 3-16. [CrossRef]

2. Långström, B.; Day, K.R. Damage, control and management of weevil pests, especially Hylobius abietis. In Bark and Wood Boring Insects in Living Trees in Europe, A synthesis; Lieutier, F., Day, K.R., Battisti, A., Grégoire, J.C., Evans, H.F., Eds.; Springer: Dordrecht, The Netherlands, 2007; pp. 415-444. [CrossRef]

3. Lempérière, G.; Mantilleri, A.; Conord, C. Taxonomy and systematics of bark weevils. In Bark and Wood Boring Insects in Living Trees in Europe, A synthesis; Lieutier, F., Day, K.R., Battisti, A., Grégoire, J.C., Evans, H.F., Eds.; Springer: Dordrecht, The Netherlands, 2007; pp. 317-330. [CrossRef]

4. Zumr, V.; Starý, P. Monitoring of seasonal occurrence of Hylobius abietis (L.) (Col., Curculionidae) in different forest environments of a model area. J. Appl. Entomol. 1994, 118, 361-364. [CrossRef]

5. Zumr, V.; Starý, P.; Dostálková, I. Monitoring of Hylobius abietis (L.) (Col., Curculionidae) populations by two types of baited pitfall traps. Anz. Schadlingsk. Pflanz. Umwelt. 1994, 67, 90-92. [CrossRef]

6. Day, K.R.; Leather, S.R. Threats to forestry by insect pests in Europe. In Forests and Insects; Watt, A.D., Stork, N.E., Hunter, M.D., Eds.; Chapman \& Hall: London, UK, 1997; pp. 177-205.

7. Eidmann, H.H.; Lindelow, A. Estimates and measurements of pine weevil feeding on conifer seedlings: their relationships and application. Can. J. For. Res. 1997, 27, 1068-1073. [CrossRef]

8. Solbreck, C. Dispersal distances of migrating pine weevils, Hylobius abietis, Coleoptera: Curculionidae. Entomol. Exp. Appl. 1980, 28, 123-131. [CrossRef]

9. Månsson, P.E.; Schlyter, F. Hylobius pine weevils adult host selection and antifeedants: Feeding behaviour on host and non-host woody Scandinavian plants. Agric. For. Entomol. 2004, 6, 165-171. [CrossRef]

10. Wallertz, K.; Nordenhem, H.; Nordlander, G. Damage by the pine weevil Hylobius abietis to seedlings of two native and five introduced tree species in Sweden. Silva. Fenn. 2014, 48, 1-14. [CrossRef]

11. Day, K.R.; Nordlander, G.; Kenis, M.; Halldorson, G. General biology and life cycles of bark weevils. In Bark and Wood Boring Insects in Living Trees in Europe, A synthesis; Lieutier, F., Day, K.R., Battisti, A., Gregoire, J.C., Evans, H., Eds.; Springer: Dordrecht, The Netherlands, 2007; pp. 331-349. [CrossRef]

12. Grégoire, J.C.; Evans, H.F. Damage and control of BAWBILT organisms an overview. In Bark and Wood Boring Insects in Living Trees in Europe, A synthesis; Lieutier, F., Day, K.R., Battisti, A., Gregoire, J.C., Evans, H., Eds.; Springer: Dordrecht, The Netherlands, 2007; pp. 19-37. [CrossRef]

13. Galko, J.; Gubka, A.; Vakula, J. Praktické skúsenosti s využitím lapacích kôr na zníženie škôd spôsobených tvrdoňom smrekovým na mladých výsadbách ihličnatých drevín (Experience with pine weevils trapping by bark pieces to reduce damage on conifer saplings). In Proceedings of the Aktuálne Problémy V Ochrane Lesa 2012, Nový Smokovec, Slovakia, 12-13 April 2012; Kunca, A., Ed.; National Forest Centre: Zvolen, Slovakia, 2012; pp. 60-64. (In Slovak).

14. Galko, J.; Ondruš, J.; Rell, S.; Gubka, A.; Vakula, J. Využitie lapacích kôr pri monitoringu populačnej hustoty tvrdoňa smrekového a lykokazov rodu Hylastes (The use of trapping bark pieces in monitoring of population density of pine weevil and Hylastes bark beetles). In Proceedings of the Aktuálne Problémy V Ochrane Lesa 2013, Nový Smokovec, Slovakia, 25-26 April 2013; Kunca, A., Ed.; National Forest Centre: Zvolen, Slovakia, 2013; pp. 142-145. (In Slovak).

15. Rell, S.; Galko, J.; Lalík, M. Mechanické spôsoby ochrany sadeníc proti škodám spôsobeným zrelostným žerom tvrdoňa smrekového (Hylobius abietis L.) (Mechanical measures in saplings protection against damage by the large pine weevil (Hylobius abietis L.)). In Proceedings of the Aktuálne Problémy V Ochrane Lesa 2017, Nový Smokovec, Slovakia, 26-27 January 2017; Kunca, A., Ed.; National Forest Centre: Zvolen, Slovakia, 2017; pp. 151-155. (In Slovak).

16. Zumr, V.; Starý, P. LATEX paint as an antifeedant against Hylobius abietis (L.) (Col, Curculionidae) on conifer seedlings. Anz. Schadlingsk. Pflanz. Umwelt. 1995, 68, 42-43. [CrossRef]

17. Hagner, M.; Jonsson, C. Survival after planting without soil preparation for pine and spruce seedlings protected from Hylobius abietis by physical and chemical shelters. Scan. J. Forest Res. 1995, 10, 225-234. [CrossRef]

18. Eidmann, H.H.; Nordenhem, H.; Weslien, J. Physical protection of conifer seedlings against pine weevil feeding. Scan. J. For. Res. 1996, 11, 68-75. [CrossRef] 
19. Örlander, G.; Nilsson, U. Effects of reforestation methods on pine weevil (Hylobius abietis) damage and seedling survival. Scand. J. For. Res. 1999, 14, 341-354. [CrossRef]

20. Örlander, G.; Nordlander, G. Effects of field vegetation control on pine weevil (Hylobius abietis) damage to newly planted Norway spruce seedlings. Ann. For. Sci. 2003, 60, 667-671. [CrossRef]

21. Nordlander, G.; Nordenhem, H.; Hellqvist, C. A flexible sand coating (Conniflex) for the protection of conifer seedlings against damage by the pine weevil, Hylobius abietis. Agric. For. Entomol. 2009, 11, 91-100. [CrossRef]

22. Galko, J.; Rell, S.; Kunca, A. Testovanie odolnosti voskom ošetrených sadeníc pred zrelostným žerom tvrdoňa smrekového-Súčasný stav a výskum na LOS (Resistance of wax-treated seedlings to maturation feeding of large pine weevil - current status and research at FPSC). In Proceedings of the Aktuálne problémy v ochrane lesa 2016, Nový Smokovec, Slovakia, 21-22 January 2016; Kunca, A., Ed.; National Forest Centre: Zvolen, Slovakia, 2016; pp. 165-170. (In Slovak).

23. Willoughby, I.; Moore, R.; Nisbet, T. Interim Guidance on the Integrated Management of Hylobius Abietis in UK Forestry; The Research Agency of the Forestry Commission: Bristol, UK, 2017; p. 28.

24. Modlinger, R.; Lalík, M.; Galko, J.; Lubojacký, J. Ověření ochrany výsadeb proti žíru klikoroha borového (Hylobius abietis) pomocí voskování v terénních podmínkách (Evaluation of seedlings protection against the bark beetle (Hylobius abietis) by waxing in field conditions). In Aktuálne problémy v ochrane lesa 2018, Proceedings of papers, Nový Smokovec, Slovakia, 1-2 February 2018; Kunca, A., Ed.; National Forest Centre: Zvolen, Slovakia, 2018; pp. 68-72. (In Czech)

25. Rell, S.; Galko, J.; Lalík, M. Porovnanie ošetrenia smrekových sadeníc lepom a Pellacolom proti škodám spôsobeným tvrdoňom smrekovým (Hylobius abietis) (Comparison of spruce seedlings treatment with adhesive and Pellacol against damage caused by spruce bark (Hylobius abietis)). In Proceedings of the Aktuálne problémy v ochrane lesa 2018, Nový Smrekovec, Slovakia, 1-2 February 2018; Kunca, A., Ed.; National Forest Centre: Zvolen, Slovakia, 2018; pp. 101-104. (In Slovak).

26. Rose, D. Control of the Large Pine Weevil, Hylobius abietis, L. Ph.D. Thesis, Imperial College at Silwood Park Ascot, Berkshire, UK, September 2002.

27. Olenici, N.; Bouriaud, O.; Manea, I.A. Efficient conifer seedling protection against pine weevil damage using neonicotinoids. Balt. For. 2018, 24, 201-209.

28. Gubka, A.; Kunca, A.; Vakula, J.; Galko, J.; Nikolov, Ch.; Rell, S.; Zúbrik, M.; Leontovyč, R. Máme vysokú spotrebu pesticídov? (Do we have high pesticide usage?). In Proceedings of the Aktuálne problémy v ochrane lesa 2017, Nový Smrekovec, Slovakia, 26-27 January 2017; Kunca, A., Ed.; National Forest Centre: Zvolen, Slovakia, 2017; pp. 103-109.

29. Brixey, J.M.; Moore, R.; Milner, A.D. Effect of entomopathogenic nematode (Steinernema carpocapsae Weiser) application technique on the efficacy and distribution of infection of the large pine weevil (Hylobius abietis L.) in stumps of Sitka spruce (Picea sitchensis Carr.) created at different times. For. Ecol. Manag. 2006, 226, 161-172. [CrossRef]

30. Dillon, A.B.; Ward, D.; Downes, M.J.; Griffin, C.T. Suppression of the large pine weevil Hylobius abietis (L.) (Coleoptera: Curculionidae) in pine stumps by entomopathogenic nematodes with different foraging strategies. Biol. Control 2006, 38, 217-226. [CrossRef]

31. Purrini, K. Nosema hylobii $n$. sp. (Nosematidae, Microsporida), a new microsporidian parasite of Hylobius abietis L. (Curculionidae, Coleoptera). Z. Angew. Entomol. 2009, 92, 1-8. [CrossRef]

32. Williams, C.D.; Dillon, A.B.; Harvey, C.D.; Hennessy, R.; Mc Namara, L.; Griffin, C.T. Control of a major pest of forestry, Hylobius abietis, with entomopathogenic nematodes and fungi using eradicant and prophylactic strategies. For. Ecol. Manag. 2013, 305, 212-222. [CrossRef]

33. Harvey, C.D.; Griffin, C.T. Local host-dependent persistence of the entomopathogenic nematode Steinernema carpocapsae used to control the large pine weevil Hylobius abietis. BioControl 2016, 61, 185-193. [CrossRef]

34. Kapranas, A.; Malone, B.; Quinn, S.; Mc Namara, L.; Williams, C.D.; O’Tuama, P.; Peters, A.; Griffin, C.T. Efficacy of entomopathogenic nematodes for control of large pine weevil, Hylobius abietis: Effects of soil type, pest density and spatial distribution. J. Pest. Sci. 2017, 90, 495-505. [CrossRef]

35. Wegensteiner, R.; Tkaczuk, C.; Bałazy, S.; Griesser, S.; Rouffaud, M.A.; Stradner, A.; Steinwender, B.M.; Hager, H.; Papierok, B. Occurrence of pathogens in populations of Ips typographus, Ips sexdentatus (Coleoptera, Curculionidae, Scolytinae) and Hylobius spp. (Coleoptera, Curculionidae, Curculioninae) from Austria, Poland and France. Acta Protozool. 2015, 3, 219-232. [CrossRef] 
36. Ansari, M.A.; Butt, T.M. Susceptibility of different developmental stages of large pine weevil Hylobius abietis (Coleoptera: Curculionidae) to entomopathogenic fungi and effect of fungal infection to adult weevils by formulation and application methods. J. Invertebr. Pathol. 2012, 111, 33-40. [CrossRef] [PubMed]

37. Vega, F.E.; Meyling, N.V.; Luangsa-Ard, J.J.; Blackwell, M. Chapter 6-Fungal Entomopathogens. In Insect Pathology; Vega, F.E., Kaya, H.K., Eds.; Academic Press: San Diego, CA, USA, 2012; pp. 171-220. [CrossRef]

38. Lacey, L.A.; Grzywacz, D.; Shapiro-Ilan, D.I.; Frutos, R.; Brownbridge, M.; Goettel, M.S. Insect pathogens as biological control agents: Back to the future. J. Invertebr. Pathol. 2015, 132, 1-41. [CrossRef] [PubMed]

39. De Faria, M.R.; Wraight, S.P. Mycoinsecticides and mycoacaricides: A comprehensive list with worldwide coverage and international classification of formulation types. Biol. Control 2007, 43, 237-256. [CrossRef]

40. Reddy, K.R.K.; Praveen Kumar, D.; Reddy, K.R.N. Entomopathogenic fungi: A potential bioinsecticide. Kavaka 2013, 41, 23-32.

41. Zimmermann, G. Review on safety of the entomopathogenic fungi Beauveria bassiana and Beauveria brongniartii. Biocontrol. Sci. Techn. 2007, 17, 553-596. [CrossRef]

42. Jaronski, S.T. Mass production of entomopathogenic fungi: State of the art. In Mass Production of Beneficial Organisms; Morales-Ramos, J., Rojas, M.G., Shapiro-Ilan, D., Eds.; Academic Press: Amsterdam, The Netherlands, 2014; pp. 357-413.

43. Augustyniuk-Kram, A.; Kram, K.J. Entomopathogenic fungi as an important natural regulator of insect outbreaks in forests (Review). In Forest Ecosystems-More than Just Trees; Blanco, J.A., Lo, Y.H., Eds.; InTech Press: Rijeka, Croatia, 2012; pp. 265-294.

44. Gerdin, S. Observations on pathogens and parasites of Hylobius abietis (Coleoptera: Curculionidae) in Sweden. J. Invertebr. Pathol. 1977, 30, 263-264. [CrossRef]

45. Glare, T.R.; Reay, S.D.; Nelson, T.L.; Moore, R. Beauveria caledonica is a naturally occurring pathogen of forest beetles. Mycol. Res. 2008, 112, 352-360. [CrossRef]

46. Samsinakova, A.; Novák, V. Eine Methode zur integrierten Bekämpfung des Rüsselkäfers (Hylobius abietis L.). Anz. Schadlingsk. Pflanz. Umwelt. 1967, 40, 22-27.

47. Waldenfels, J. Versuche zur Bekämpfung von Hylobius abietis L. (Coleopt., Curculionidae). Anz. Schadlingsk. Pflanz. Umwelt. 1975, 48, 21-25. [CrossRef]

48. Wegensteiner, R.; Führer, E. Zur Wirksamkeit von Beauveria bassiana (Bals.) Vuill. gegen Hylobius abietis L. (Col.: Curculionidae). Entomophaga 1988, 33, 339-348. [CrossRef]

49. Wegensteiner, R. The efficacy of Beauveria bassiana, B. brongniartii and B. tenella against Hylobius abietis (Col., Curcul.). In Proceedings of the International Conference on Biopesticides, Theory and Practice, České Budějovice, Czechoslovakia, 25-28 September 1989; Jegorov, A., Matha, V., Eds.; Czechoslovak Academy of Sciences: České Budějovice, Czechoslovakia, 1989; pp. 238-242.

50. Mc Namara, L.; Kapranas, A.; Williams, C.D.; O’Tuama, P.; Kavanagh, K.; Griffin, C.T. Efficacy of entomopathogenic fungi against large pine weevil, Hylobius abietis, and their additive effects when combined with entomopathogenic nematodes. J. Pest. Sci. 2018, 91, 1407-1419. [CrossRef]

51. Zumr, V.; Starý, P. The occurrence of the large pine weevil, Hylobius abietis (L.), in individual forest zones. For. Ecol. Manag. 1992, 51, 251-258. [CrossRef]

52. Voolma, K.; Sibul, I. The effect of collecting fluid on the catch results of Hylobius abietis in pitfall traps. Agron. Res. 2006, 4, 457-460.

53. Humber, R.A. Identification of entomopathogenic fungi. In Manual of Techniques in Invertebrate Pathology; Lacey, L.A., Ed.; Academic Press: Amsterdam, The Netherlands, 2012; pp. 151-187.

54. Rehner, S.A.; Buckley, E.P. A Beauveria phylogeny inferred from ITS and EF1- $\alpha$ sequences: evidence for cryptic diversification and links to Cordyceps teleomorphs. Mycologia 2005, 97, 84-98. [CrossRef] [PubMed]

55. Rehner, S.A.; Minnis, A.M.; Sung, G.H.; Luangsa-ard, J.J.; Devotto, L.; Humber, R.A. Phylogeny and systematics of the anamorphic, entomopathogenic genus Beauveria. Mycologia 2011, 103, 1055-1073. [CrossRef]

56. White, T.J.; Bruns, T.; Lee, S.; Taylor, J. Amplification and direct sequencing of fungal ribosomal RNA genes for phylogenetics. In PCR Protocols: A Guide to Methods and Applications; Innis, M.A., Gelfand, D.H., Sninsky, J.J., White, T.J., Eds.; Academic Press: San Diego, CA, USA, 1990; pp. 315-322.

57. Gardes, M.; Bruns, T.D. ITS primers with enhanced specificity for Basidiomycetes: application to identification of mycorrhizae and rusts. Mol. Ecol. 1993, 2, 113-118. [CrossRef] [PubMed] 
58. Altschul, S.F.; Madden, T.L.; Schaffer, A.A.; Zhang, J.; Zhang, Z.; Miller, W.; and Lipman, D.J. Gapped BLAST and PSI-BLAST: A new generation of protein database search programs. Nucleic Acids Res. 1997, 25, 3389-3402. [CrossRef]

59. Barta, M. Pathogenicity assessment of entomopathogenic fungi infecting Leptoglossus occidentalis (Heteroptera: Coreidae). Czech. Mycol. 2010, 62, 67-78. [CrossRef]

60. Leather, S.R.; Ahmed, S.I.; Hogan, L. Adult feeding preferences of the large pine weevil, Hylobius abietis (Coleoptera: Curculionidae). Eur. J. Entomol. 1994, 91, 385.

61. Robertson, J.L.; Jones, M.M.; Olguin, E.; Alberts, B. Bioassays with Arthropods, 3rd ed.; CRC Press: Boca Raton, FL, USA, 2017; p. 194.

62. Medo, J.; Michalko, J.; Medová, J.; Cagáň, L'. Phylogenetic structure and habitat associations of Beauveria species isolated from soils in Slovakia. J. Invertebr. Pathol. 2016, 140, 46-50. [CrossRef] [PubMed]

63. Popowska-Nowak, E.; Skrzecz, I.; Tumialis, D.; Pezowicz, E.; Samborska, I.; Góral, K. Entomopathogenic fungi in the soils of forest plantations: towards the control of large pine weevil, Hylobius Abietis. Balt. For. 2016, 22, 8-15.

64. Bisset, J.; Widden, P. A new species of Beauveria isolated from Scottish moorland soil. Can. J. Bot. 1988, 66, 361-362. [CrossRef]

65. Reay, S.D.; Brownbridge, M.; Cummings, N.J.; Nelson, T.L.; Souffre, B.; Lignon, C.; Glare, T.R. Isolation and characterization of Beauveria spp. associated with exotic bark beetles in New Zealand Pinus radiata plantation forests. Biol. Control. 2008, 46, 484-494. [CrossRef]

66. Barta, M.; Kautmanová, I.; Čičková, H.; Ferenčík, J.; Florián, Š.; Novotný, J.; Kozánek, M. Hypocrealean fungi associated with populations of Ips typographus in West Carpathians and selection of local Beauveria strains for effective bark beetle control. Biologia 2018, 73, 53-65. [CrossRef]

67. Markova, G. Pathogenicity of several entomogenous fungi to some of the most serious forest insect pest in Europe. IOBC/WPRS Bull. 2000, 23, 231-239.

68. Zhang, S.L.; He, L.M.; Chen, X.; Hueng, B. Beauveria lii sp. nov. isolated from Henosepilachna vigintioctopunctata. Mycotaxon 2012, 121, 199-206. [CrossRef]

69. Chen, M.J.; Huang, B.; Li, Z.; Spatafora, J.W. Morphological and genetic characterisation of Beauveria sinensis sp. nov. from China. Mycotaxon 2013, 124, 301-308. [CrossRef]

70. Chen, W.H.; Han, Y.F.; Liang, Z.Q.; Jin, D.C. A new araneogenous fungus in the genus Beauveria from Guizhou, China. Phytotaxa 2017, 302, 57-64. [CrossRef]

71. Agrawal, Y.; Mual, P.; Shenoy, B.D. Multi-gene genealogies reveal cryptic species Beauveria rudraprayagi sp. nov. from India. Mycosphere 2014, 5, 719-736. [CrossRef]

72. Ariyawansa, H.A.; Hyde, K.D.; Jayasiri, S.C.; Buyck, B.; Chethana, K.W.T. Fungal diversity notes 111-252taxonomic and phylogenetic contributions to fungal taxa. Fungal Divers. 2015, 75, 27-274. [CrossRef]

73. Robène-Soustrade, I.; Jouen, E.; Pastou, D.; Payet-Hoarau, M.; Goble, T.; Linderme, D.; Lefeuvre, P.; Calmès, C.; Reynaud, B.; Nibouche, S.; et al. Description and phylogenetic placement of Beauveria hoplocheli sp. nov. used in the biological control of the sugarcane white grub, Hoplochelus marginalis, on Reunion Island. Mycologia 2015, 107, 1221-1232. [CrossRef] [PubMed]

74. Imoulan, A.; Wu, H.J.; Lu, W.L.; Li, Y.; Li, B.B.; Yang, R.H.; Wang, W.J.; Wang, X.L.; Kirk, P.M.; Yao, Y.J. Beauveria medogensis sp. nov., a new fungus of the entomopathogenic genus from China. J. Invertebr. Pathol. 2016, 139, 74-81. [CrossRef] [PubMed]

75. Girling, R.D.; Ennis, D.; Dillon, A.B.; Griffin, C.T. The lethal and sub-lethal consequences of entomopathogenic nematode infestation and exposure for adult pine weevils, Hylobius abietis (Coleoptera: Curculionidae). J. Invertebr. Pathol. 2010, 104, 195-202. [CrossRef] [PubMed]

76. Eidmann, H.H. Integrated management of pine weevil (Hylobius abietis L.) populations in Sweden. In Current Topics in Forest Entomology; Forest Service General Technical Report WO-8; USDA: Washington, DC, USA, 1979; pp. 103-109.

77. Christiansen, E. Laboratory study on factors influencing pre-imaginal development in Hylobius abietis L. (Col., Curculionidae). Norsk Entomol. Tidsskr. 1971, 18, 1-8.

78. Christiansen, E.; Bakke, A. Temperature preference in adults of Hylobius abietis L. (Coleoptera: Curculionidae) during feeding and oviposition. Z. Angew. Entomol. 1968, 62, 83-89. [CrossRef]

79. Wainhouse, D.; Boswell, R.; Ashburner, R. Maturation feeding and reproductive development in adult pine weevil, Hylobius abietis (Coleoptera Curculionidae). B Entomol. Res. 2004, 94, 81-87. [CrossRef] 
80. Gardner, W.A.; Sutton, R.M.; Noblet, R. Persistence of Beauveria bassiana, Nomuraea rileyi, and Nosema necatrix on soybean foliage. Environ. Entomol. 1977, 6, 616-618. [CrossRef]

81. Huang, B.F.; Feng, M.G. Comparative tolerances of various Beauveria bassiana isolates to UV-B irradiation with a description of a modeling method to assess lethal dose. Mycopathologia 2009, 168, 145-152. [CrossRef]

82. Posadas, J.B.; Angulo, L.M.; Mini, J.I.; Lecuona, R.E. Natural tolerance to UV-B and assessment of photoprotectants in conidia of six native isolates of Beauveria bassiana (Bals-Criv) Vuillemin. World Appl. Sci. J. 2012, 20, 1024-1030. [CrossRef]

83. Ignoffo, C.M.; Garcia, C.; Hostetter, D.L.; Pinnell, R.E. Vertical movement of conidia of Nomuraea rileyi through sand and loam soils. J. Econ. Entomol. 1977, 70, 163-164. [CrossRef]

84. Fargues, J.; Goettel, M.S.; Smits, N.; Ouedraogo, A.; Vidal, C.; Lacey, L.A.; Lomer, C.J.; Rougier, M. Variability in susceptibility to simulated sunlight of conidia among isolates of entomopathogenic Hyphomycetes. Mycopathologia 1996, 135, 171-181. [CrossRef] [PubMed]

85. Morley-Davies, J.; Moore, D.; Prior, C.J. Screening of Metarhizium and Beauveria spp. conidia with exposure to simulated sunlight and a range of temperatures. Mycol. Res. 1995, 100, 31-38. [CrossRef]

86. Kouassi, M.; Coderre, D.; Todorova, S.I. Effect of plant type on the persistence of Beauveria bassiana. Biocontrol Sci. Techn. 2003, 13, 415-427. [CrossRef]

87. Inglis, G.D.; Goettel, M.S.; Johnson, D.L. Persistence of the entomopathogenic fungus, Beauveria bassiana, on phylloplanes of crested wheatgrass and alfalfa. Biol. Control 1993, 3, 258-270. [CrossRef]

(C) 2019 by the authors. Licensee MDPI, Basel, Switzerland. This article is an open access article distributed under the terms and conditions of the Creative Commons Attribution (CC BY) license (http://creativecommons.org/licenses/by/4.0/). 